\section{6 OPEN ACCESS}

\title{
A novel mouse model that develops spontaneous arthritis and is predisposed towards atherosclerosis
}

\author{
Shawn Rose, ${ }^{1}$ Mesut Eren, ${ }^{2}$ Sheila Murphy, ${ }^{2}$ Heng Zhang, ${ }^{3,4}$ Colby Shad Thaxton, ${ }^{3,4}$ \\ Jaime Chowaniec, ${ }^{1}$ Emily A Waters, ${ }^{5}$ Thomas J Meade, ${ }^{5}$ Douglas E Vaughan, ${ }^{2}$ \\ Harris Perlman ${ }^{1}$
}

\begin{abstract}
- Additional material is published online only. To view these files please visit the journal online (http:/dx.doi.org/ 10.1136/annrheumdis-2012201431).

1 Division of Rheumatology, Department of Medicine, Northwestern University Feinberg School of Medicine, Chicago, Illinois, USA ${ }^{2}$ Cardiovascular Research Institute, Northwestern University Feinberg School of Medicine, Chicago, Illinois, USA ${ }^{3}$ Institute for

BioNanotechnology, Northwestern University Feinberg School of Medicine, Chicago, Illinois, USA ${ }^{4}$ Department of Urology, Northwestern University Feinberg School of Medicine, Chicago, Illinois, USA 5Department of Molecular Biosciences, Northwestern University, Evanston, Illinois, USA
\end{abstract}

\section{Correspondence to}

Harris Perlman, Northwestern University Feinberg School of Medicine, Department of Medicine, Division of Rheumatology, 240 East Huron Street, McGaw M338, Chicago, IL 60611, USA:

h-perlman@northwestern.edu

Accepted 6 May 2012

Published Online First

26 June 2012

\section{ABSTRACT}

Objectives Patients with rheumatoid arthritis (RA)

have a reduced life expectancy due to increased cardiovascular disease. The lack of a suitable animal model resembling both $\mathrm{RA}$ and atherosclerosis has hindered studies demonstrating a direct link between systemic inflammation in RA and the development of atherosclerosis. Our objective was to overcome this barrier by generating an animal model $\left(\mathrm{K} / \mathrm{Bx}^{\mathrm{g}}{ }^{\mathrm{g}}\right)$ that spontaneously develops both RA-like disease and atherosclerosis.

Methods Arthritis severity was evaluated using clinical indices and immunohistochemical staining of ankle joint specimens. Aortic atherosclerosis was delineated via Sudan IV staining and immunohistochemical analysis. Serum cholesterol and lipoprotein levels were measured using enzymatic assays. Serum levels of cytokines, chemokines and adipokines were determined by Luminex assays.

Results $\mathrm{K} / \mathrm{BxA}^{\mathrm{g} 7}$ mice developed a destructive arthropathy followed by prominent aortic atherosclerosis. These animals also displayed dyslipidaemia, characterised by reduced serum levels of total cholesterol and highdensity lipoprotein, and increased low-density lipoprotein (LDL)/vLDL compared with control mice. Further, there were higher levels of circulating inflammatory mediators, such as interleukin-6, sRANKL and CCL5 in atherosclerotic $\mathrm{K} / \mathrm{BxA}^{\mathrm{g} 7}$ mice compared with controls. Treatment with etanercept reduced arthritis and atherosclerosis development in $\mathrm{K} / \mathrm{BxA}^{\mathrm{g} 7}$ mice.

Conclusions $\mathrm{K} / \mathrm{BxA}^{\mathrm{g} 7}$ mice recapitulate the same sequence of events occurring in patients with RA, namely an erosive, inflammatory arthritis followed by atherosclerosis. These data suggest that the $\mathrm{K} / \mathrm{BxA}^{\mathrm{g}}$ mouse is a novel system for investigating the interplay between systemic inflammation occurring in RA and the development of atherosclerosis.

\section{INTRODUCTION}

Rheumatoid arthritis (RA) is a chronic inflammatory and destructive arthropathy that affects $1 \%$ of the population. ${ }^{1}$ Patients with RA are at increased risk for premature cardiovascular (CV) events, which contributes greatly to their high mortality. ${ }^{2} 3$ This elevated CV risk is independent of traditional risk factors and may be related to increased systemic inflammation. Further, dyslipidaemia, characterised by elevated serum levels of total cholesterol (TC) and low-density lipoprotein (LDL) and decreased high-density lipoprotein (HDL), also raises CV risk in RA. ${ }^{4}$ To date, advancement in understanding the relationships among inflammatory arthritis, dyslipidaemia and atherosclerosis in RA has been limited by the lack of a representative animal model.

Mice expressing the KRN T-cell receptor (TCR) in the context of the major histocompatibility complex (MHC) Class II Allele I ${ }^{\mathrm{Ak}}\left(\mathrm{A}^{\mathrm{g} 7}\right)$ develop a spontaneous, erosive arthritis that resembles RA. ${ }^{5} \mathrm{~A}^{\mathrm{7}}$ MHC class II alleles present endogenous glucose6-phosphate isomerase (G6PI) peptides that are recognised by the KRN TCR. Innate and adaptive immune components including B cells, T cells, neutrophils, mast cells, macrophages, complement factors, inflammatory cytokines and Fc receptors have been shown to be instrumental for the development of arthritis in these animals. ${ }^{6-8}$ The arthritis is transferrable to naive mice through injection of serum containing anti-G6PI antibodies, ${ }^{9}$ with the resulting inflammatory arthritis in recipient mice resembling the effector phase. $\mathrm{K} / \mathrm{BxA}^{\mathrm{g} 7}$ mice also develop cardiac valvulitis, another feature occurring in RA. ${ }^{10}$ Thus, the $\mathrm{K} / \mathrm{BxA}^{\mathrm{g} 7}$ mouse represents an ideal animal model to examine the influence of inflammatory arthritis on the development of atherosclerosis.

\section{METHODS}

Animals

KRN mice (C57BL/6) were a gift from Drs Diane Mathis and Christophe Benoist. $\mathrm{A}^{\mathrm{g} 7}$ (C57BL/6) mice were provided by Dr Paul Allen. C57BL/6 (Jackson Laboratory, Bar Harbor, Maine, USA), and the NOD mice (Taconic, Germantown, New York, USA) were purchased. Genotyping was confirmed by Transnetyx (Memphis, Tennessee, USA) and flow cytometry. Equal numbers of male and female mice were fed chow or Harlan Teklad atherogenic diet TD.94059 (Harlan, Houston, Texas, USA) containing $15.8 \%$ fat and $1.2 \%$ cholesterol. A subset of $\mathrm{K} / \mathrm{BxA}^{\mathrm{g} 7}$ mice was injected subcutaneously with phosphate buffered saline (PBS) or $0.8 \mathrm{mg} / \mathrm{kg}$ etanercept twice weekly for 13 weeks. All studies were approved by the IACUC at Northwestern University, and mice were maintained within the Center for Comparative Medicine.

\section{Scoring and induction of arthritis}

Ankle width was measured using calipers. Clinical score (total=12) for four paws measured disease severity, scored as $0=$ normal, $1=$ swollen wrist/ 
ankle, 2=swelling extending to forepaw/hindpaw, 3=swelling extending to digits. Clinical damage index (total=40) for four paws was determined by summing the number of irreversibly hyper-extended or flexed joints. Ankle joints were fixed in 10\% formalin and decalcified. For the serum transfer-induced arthritis (STIA) experiments, C57BL/6 mice were injected intraperitoneally with $100 \mu \mathrm{l}$ of $\mathrm{K} / \mathrm{BxN}$ serum in $200 \mu \mathrm{l}$ PS.

\section{Immunohistochemistry}

Paraffin-embedded ankle sections were stained with $\mathrm{H} \& \mathrm{E}$. Paraffin-embedded aortic sinus sections were stained with Masson's Trichrome, rat antimouse F4/80 (clone BM8), or rat antimouse CD45 (Caltag) antibodies. Imaging was performed using an Olympus DP40 microscope (Tokyo, Japan) equipped with a DP71 camera.

\section{Evaluation of atherosclerosis}

Peripheral blood was harvested by cardiac puncture, followed by ventricular perfusion with $20 \mathrm{ml}$ of PBS. Aortas were excised, fixed with 10\% formalin, and stained with Sudan IV (SigmaAldrich, St Louis, Missouri, USA). Atherosclerosis was quantitated by computer-assisted morphometric analysis (ImagePro 6.3 software) of whole aortic (aortic root to iliac bifurcation) specimens. Results were expressed as the percentage of Sudan
IV stained lesion area (calculated by Sudan IV stained area/total aortic area $\times 100$ ).

\section{Serum analysis}

Serum cytokine and chemokine levels were assessed using Luminex-based (Austin, Texas, USA) 27-plex assays (Affymetrix, Santa Clara, California, USA) according to the manufacturer's instructions. Serum TC, low-density lipoprotein/very lowdensity lipoprotein (LDL/vLDL) and HDL levels were measured using enzymatic assays according to the manufacturer's instructions (AbCam, Cambridge, Massachusetts, USA).

\section{Statistical analysis}

Repeated-measure, two-way analysis of variance with Bonferroni post-tests were used for arthritis analyses. Student's t tests were used to compare Sudan IV staining, lipid and cytokine levels between groups. Linear regression analysis was used with TC, LDL/vLDL or $\mathrm{HDL}$ as $\mathrm{X}$ variable predictors, and atherosclerotic burden as the $\mathrm{Y}$ variable. Statistical significance was established at $\mathrm{p}<0.05$.

\section{RESULTS}

$\mathrm{K} / \mathrm{Bx} \mathrm{A}^{\mathrm{g} 7}$ mice develop a severe, destructive arthropathy In order to understand the interplay between systemic inflammation that occurs in RA-like disease and atherosclerosis,

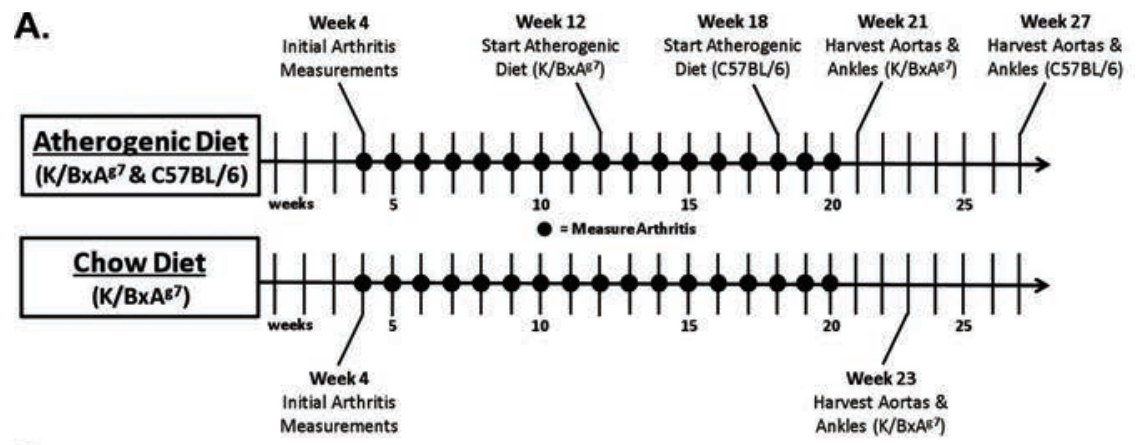

B.
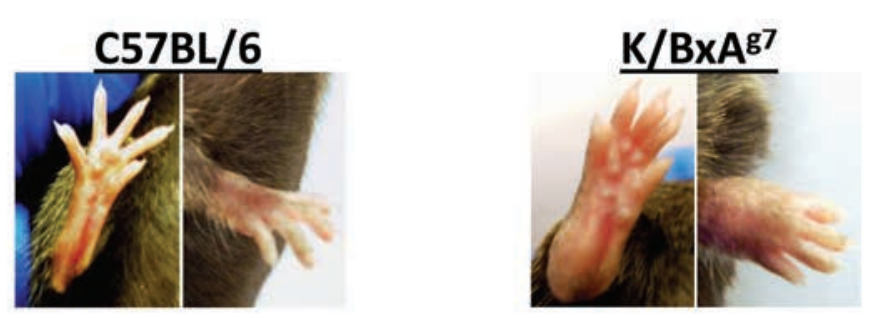

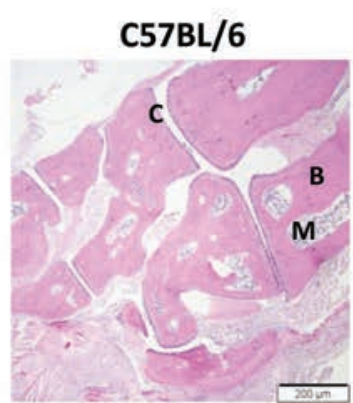

Atherogenic

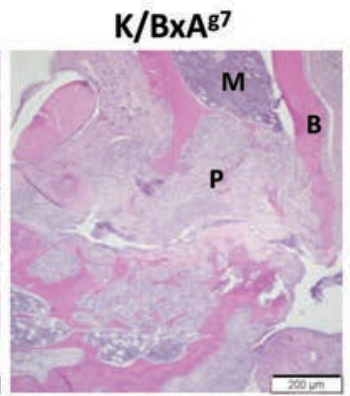

Chow

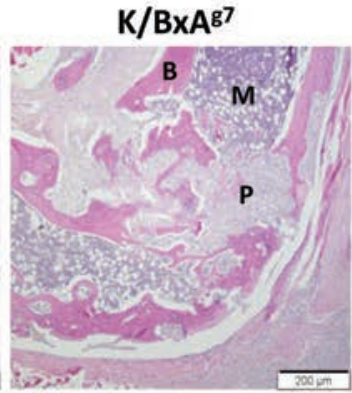

Atherogenic
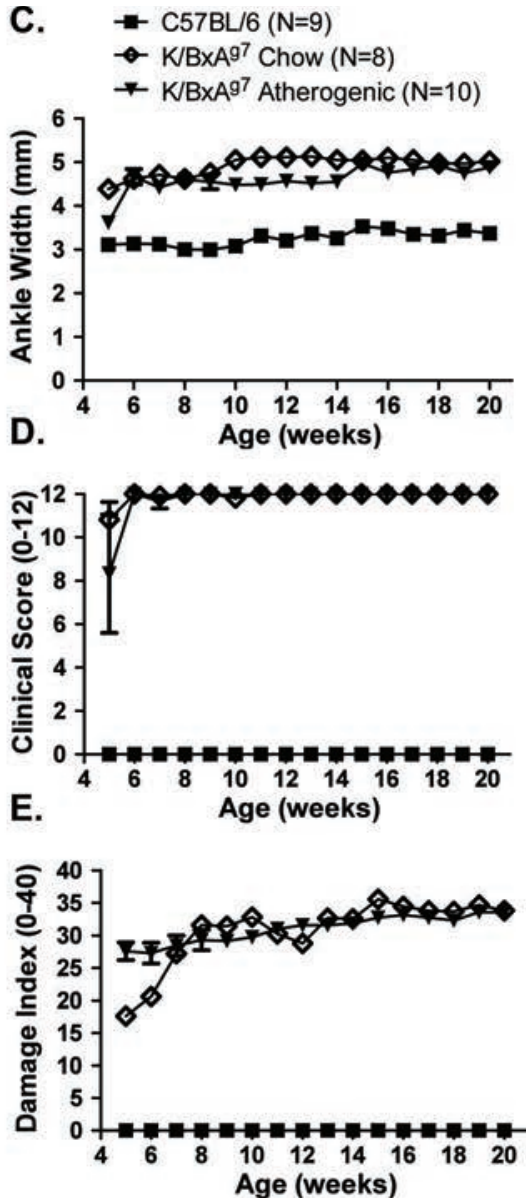

Figure $1 \mathrm{~K} / \mathrm{BxA}^{\mathrm{g} 7}$ mice develop a severe, destructive arthropathy. (A) Experimental timeline. (B) Forepaw and hindpaw images (upper panel) from 6 -week-old $\mathrm{C} 57 \mathrm{BL} / 6$ and $\mathrm{K} / \mathrm{BxA}^{\mathrm{g} 7}$ mice. H\&E staining of representative ankle joint specimens (lower panel) from $\mathrm{C} 57 \mathrm{BL} / 6$ and $\mathrm{K} / \mathrm{BxA}{ }^{97}$ mice fed an atherogenic diet, or $\mathrm{K} / \mathrm{BxA}^{\mathrm{g} 7}$ mice fed chow. $(\mathrm{P})=$ pannus $(B)=$ bone $(C)=$ cartilage $(M)=$ bone marrow. Mean $\pm S E M(C)$ ankle width, $(D)$ clinical score and $(\mathrm{E})$ damage index in $\mathrm{C} 57 \mathrm{BL} / 6$ (filled squares), and $\mathrm{K} / \mathrm{BxA}^{\mathrm{g} 7}$ (filled triangles) mice fed an atherogenic diet or $\mathrm{K} / \mathrm{BxA}^{\mathrm{g} 7}$ (open diamonds) mice fed chow. Statistically significant differences $(p<0.0001)$ were observed between $\mathrm{K} / \mathrm{BxA} \mathrm{A}^{\mathrm{7}}$ (atherogenic or chow diet) and $\mathrm{C} 57 \mathrm{BL} / 6 \mathrm{mice}$ at all time points. 
A.

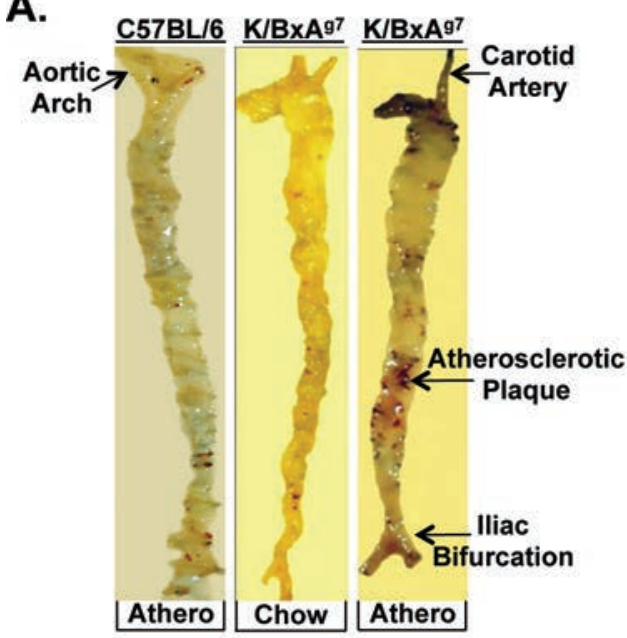

C.

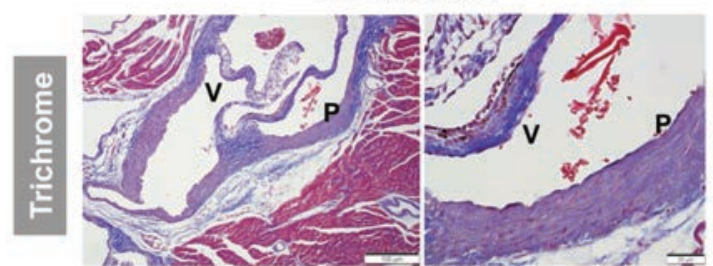

\section{Chow}
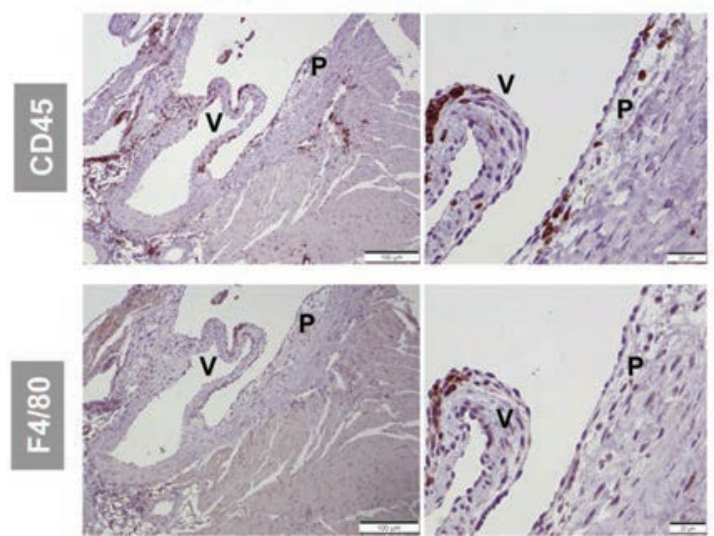

B.

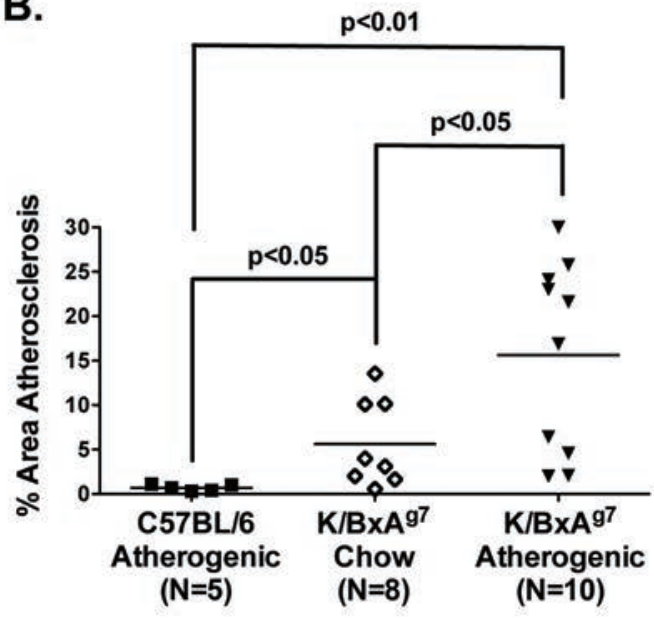

Atherogenic
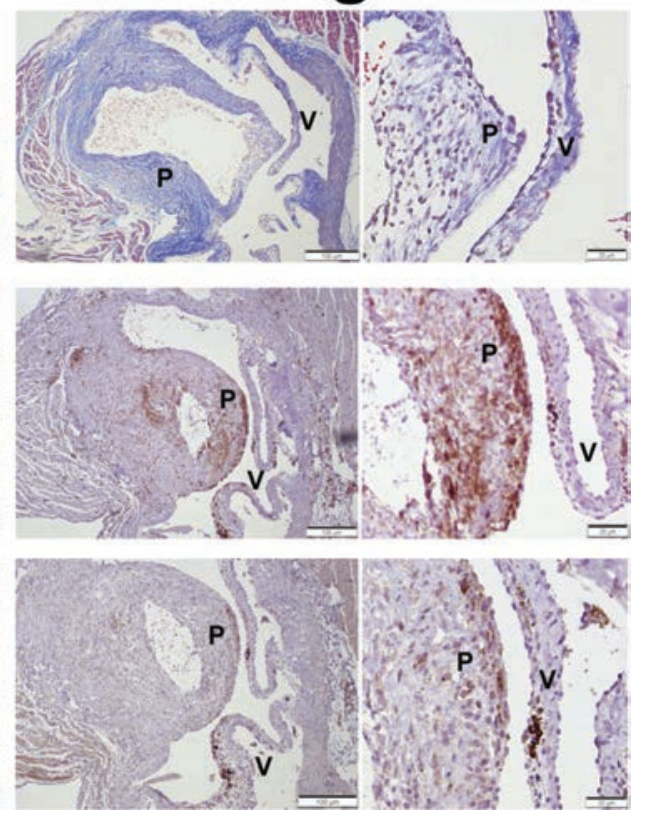

Figure $2 \mathrm{~K} / \mathrm{BxA}^{\mathrm{g} 7}$ mice are susceptible to atherosclerosis. (A) Sudan IV staining of representative aortic specimens from $\mathrm{C} 57 \mathrm{BL} / 6$ or $\mathrm{K} / \mathrm{BxA} \mathrm{g}^{\mathrm{g}}$ mice fed an atherogenic diet ('athero') or a K/BxA ${ }^{g 7}$ mouse fed chow. (B) Mean $\pm S E M$ percentage atherosclerotic area of Sudan IV stained aortic specimens from $\mathrm{K} / \mathrm{BxA}^{\mathrm{g} 7}$ (filled triangles) and $\mathrm{C} 57 \mathrm{BL} / 6$ (filled squares) mice fed an atherogenic diet, or $\mathrm{K} / \mathrm{BxA}^{\mathrm{g} 7}$ (open diamonds) mice fed chow. (C) Masson's trichrome, anti-CD45 antibody or anti-F4/80 antibody staining of aortic sinus specimens from representative $\mathrm{K} / \mathrm{BxA}^{\mathrm{g} 7}$ mice fed chow, or an atherogenic diet. $10 \times$ (left) and $40 \times$ (right) magnification, are depicted for aortic specimens. $\mathrm{P}=$ atherosclerotic plaque, $\mathrm{V}=$ aortic valve.

we generated mice $\left(\mathrm{K} / \mathrm{BxA}^{\mathrm{g}}\right)$ that express the KRN TCR transgene $(\mathrm{K})$, and the $\mathrm{MHC}$ class II Allele $\mathrm{H}-2 \mathrm{k}\left(\mathrm{A}^{\mathrm{g} 7}\right)$, which were backcrossed for several generations onto a C57BL/6 (H-2b) background. ${ }^{11}$ While $\mathrm{K} / \mathrm{BxN}$ mice ${ }^{12}$ have been used extensively to model RA, the non-obese diabetic (NOD $(\mathrm{N})$ ) background, which predisposes $\mathrm{K} / \mathrm{BxN}$ animals toward diabetes, may confound the atherosclerosis studies. At 4-5 weeks of age (figure $1 \mathrm{~A}$ ), $\mathrm{K} / \mathrm{BxA} \mathrm{A}^{\mathrm{g}}$ mice developed a severe arthropathy, as measured by histologic anklejointanalysis(figure 1B), anklewidth (figure 1C), clinicalscore (figure 1D) and damage index (figure 1E). In contrast, no arthritis was observed in control animals (C57BL/6) on a mixed $\mathrm{H}-2 \mathrm{~b}$ and $\mathrm{H}-2 \mathrm{k}\left(\mathrm{A}^{\mathrm{g}}\right)$, or a pure $\mathrm{H}-2 \mathrm{~b}$ background (unpublished data). There were also no gender differences identified between mice. Our data suggest that $\mathrm{K} / \mathrm{BxA}^{87}$ mice develop a spontaneous, destructive arthritis that mimics RA, which is in agreement with previous findings. ${ }^{13}$
$\mathrm{K} / \mathrm{BxA}^{\mathrm{g} 7}$ mice are susceptible to atherosclerosis

Patients with RA are predisposed toward atherosclerotic disease. $^{2}{ }^{3}$ To determine whether $\mathrm{K} / \mathrm{BxA} \mathrm{A}^{87}$ animals are susceptible to atherosclerosis, subgroups of mice were fed chow for 12 weeks followed by an atherogenic diet, or continued on the chow diet (figure 1A). $\mathrm{K} / \mathrm{BxA}^{97}$ mice displayed a 22-fold increase in aortic atherosclerosis compared with control mice, which exhibited negligible lesion formation even on an atherogenic diet (figures 2A,B). Further, plaque area was 2.3-fold greater in $\mathrm{K} / \mathrm{BxA}^{\mathrm{g} 7}$ mice fed an atherogenic diet compared with chow (figures 2A,B). Gender-specific differences between mice were not observed. Leucocytes and macrophages were highly present in atherosclerotic plaques from $\mathrm{K} / \mathrm{BxA}^{87}$ mice (figure $2 \mathrm{C}$ ), similar to RA patients. ${ }^{14}$ These data suggest that $\mathrm{K} / \mathrm{BxA}^{87}$ arthritic/ atherosclerotic mice develop a histological and cellular plaque composition that is reminiscent of patients with RA. 
A.

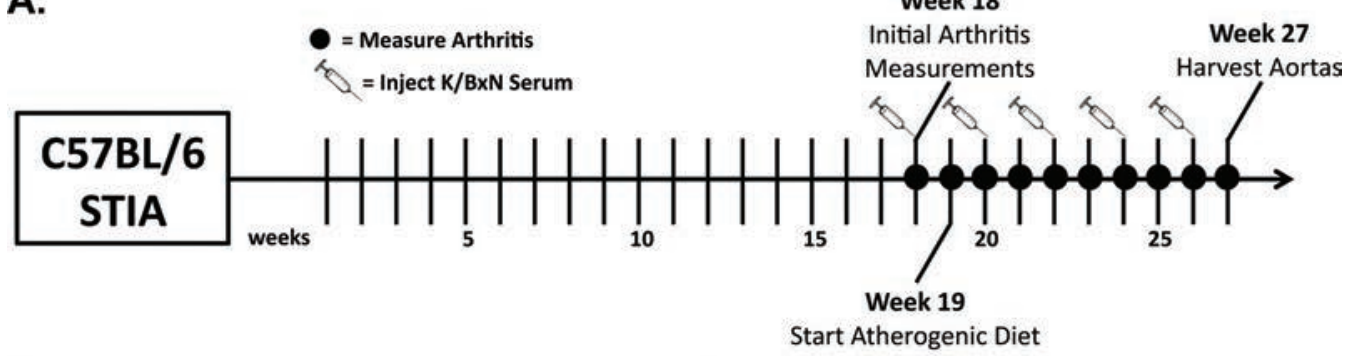

B.

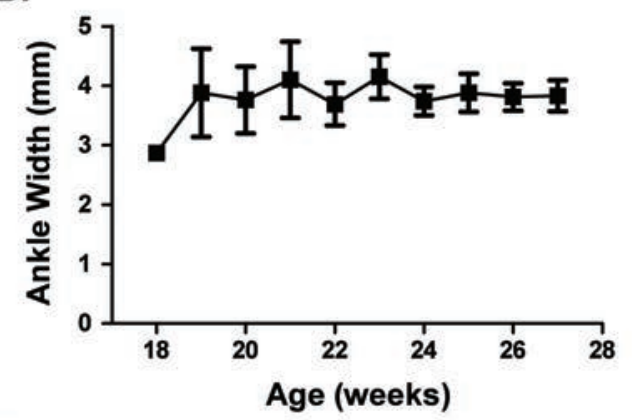

D.

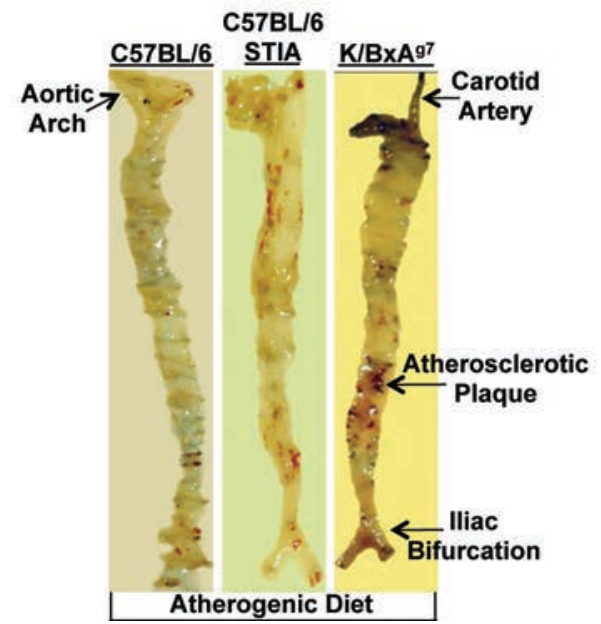

C.

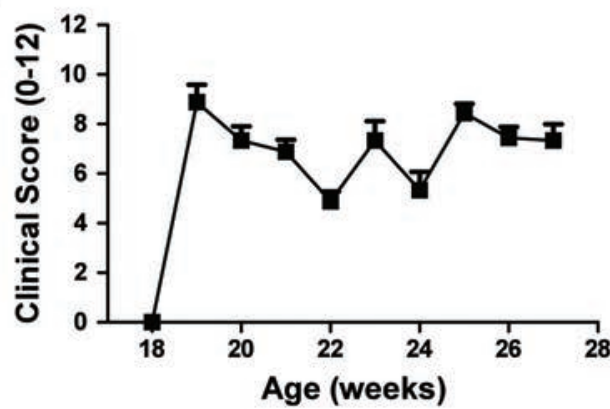

E.

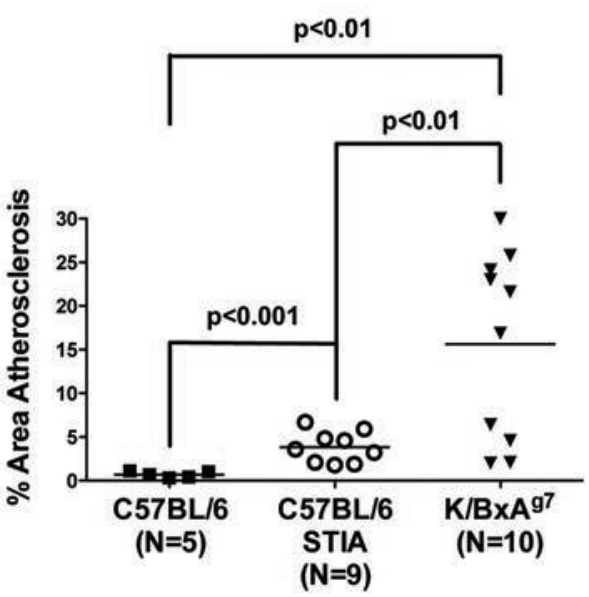

Figure 3 Induction of arthritis triggers the development of atherosclerosis in C57BL/6 mice. (A) Experimental timeline. C57BL/6 serum transferinduced arthritis (STIA) mice were intraperitoneally injected with K/BxN serum bimonthly, and (B) joint width and (C) clinical score were assessed weekly, thereafter (mean \pm SEM). (D) Sudan IV staining of a representative aortic specimen from a C57BL/6 STIA mouse. C57BL/6 and K/BxA ${ }^{97}$ mice treated as in (A) are included for comparison. (E) Percentage (mean \pm SEM) atherosclerotic area of Sudan IV stained aortic specimens from C57BL/6 (filled squares), $\mathrm{C} 57 \mathrm{BL} / 6 \mathrm{STIA}$ (open circles) and $\mathrm{K} / \mathrm{BxA}^{\mathrm{g} 7}$ (filled triangles) mice.

The K/BxN STIA mode $1^{9}$ resembles the effector phase of RA. Eighteen-week-old C57BL/6 mice were injected bimonthly with $\mathrm{K} / \mathrm{BxN}$ serum, and were fed an atherogenic diet for 9 weeks (figures $3 \mathrm{~A}-\mathrm{C}$ ). Atherosclerosis levels were 5.4 -fold higher $(\mathrm{p}<0.001)$ in STIA mice than in controls fed an atherogenic diet (figures $3 \mathrm{D}, \mathrm{E}$ ). However, plaque area was still 4.1-fold greater in $\mathrm{K} / \mathrm{BxA}{ }^{77}$ compared with STIA mice (figures $3 \mathrm{D}, \mathrm{E}$ ). Together, these data indicate that induction of inflammatory arthritis via endogenous $\left(\mathrm{K} / \mathrm{BxA}^{\mathrm{g}^{7}}\right)$ or transferred $(\mathrm{K} / \mathrm{BxN})$ arthritogenic serum provokes the development of atherosclerosis. Furthermore, arthritis and atherosclerosis in the STIA model does not require specific T-cell receptors or MHC class II alleles.

\section{$\mathrm{K} / \mathrm{BxA}^{\mathrm{g}}{ }^{7}$ mice are dyslipidaemic}

Dyslipidaemia may be an important contributor to increased CV mortality in RA. ${ }^{4} \mathrm{~K} / \mathrm{BxA}^{87}$ mice exhibited marked dyslipidaemia, characterised by reduced serum levels of TC (figure 4A, $p<0.01$ ), increased $\mathrm{LDL} / \mathrm{vLDL}$ (figure $4 \mathrm{~B}, \mathrm{p}<0.01$ ), and diminished $\mathrm{HDL}$ (figure 4C, $\mathrm{p}<0.01$ ) compared with non-arthritic controls on an atherogenic diet. However, LDL/vLDL levels were increased by 3.2-fold ( $\mathrm{p}<0.0001$ ) in $\mathrm{K} / \mathrm{BxA}^{87}$ mice fed an atherogenic diet versus chow, while TC and HDL levels were unaffected by diet (figure 4). Lower $\mathrm{HDL}$ levels in $\mathrm{K} / \mathrm{BxA}^{87}$ mice were associated with greater amounts of atherosclerosis $\left(R^{2}=0.60, p<0.05\right.$, figure $\left.3 F\right)$ whereas, TC (figure $3 \mathrm{D}$ ) and $\mathrm{LDL} / \mathrm{vLDL}$ (figure $3 \mathrm{E}$ ) were not significantly related to atherosclerotic burden. Similar to $\mathrm{K} / \mathrm{BxA}^{\mathrm{g} 7}$ mice, STIA mice demonstrated reduced levels of TC (figure $3 \mathrm{~A}, \mathrm{p}<0.01$ ) and $\mathrm{HDL}$ (figure $3 \mathrm{C}, \mathrm{p}<0.01$ ), and elevated $\mathrm{LDL} / \mathrm{vLDL}$ (figure $3 \mathrm{~B}$, $\mathrm{p}=0.12$ ) compared with non-arthritic controls. Altogether, these findings show that dyslipidaemia may contribute to the elevated atherosclerosis observed in $\mathrm{K} / \mathrm{BxA}^{87}$ mice, and that induction of arthritis elicits dyslipidaemia in normal animals.

Serum cytokines/chemokines are altered in $\mathrm{K} / \mathrm{Bx} \mathrm{A}^{97}$ mice Cytokines, chemokines and adipokines are central to the development of atherosclerosis. ${ }^{15} 16$ Serum levels of interleukin-6, 
A.

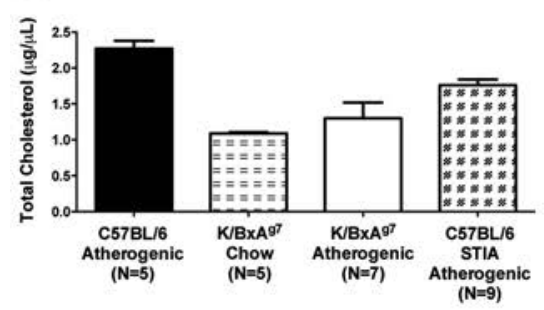

D.

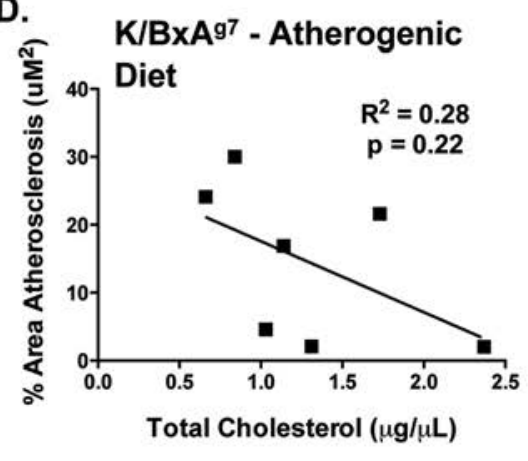

B.

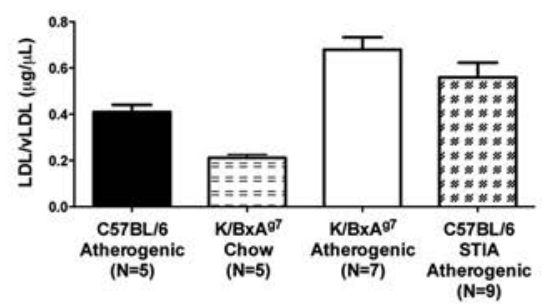

E.

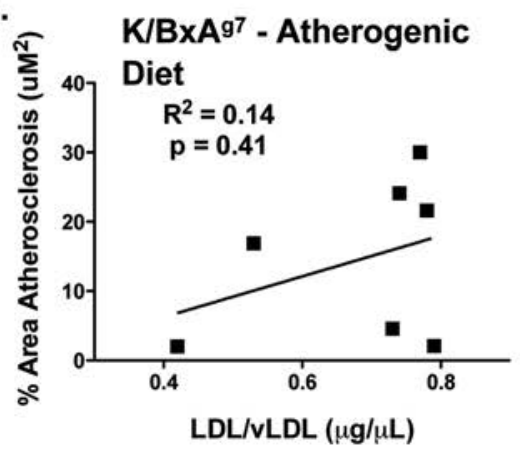

C.

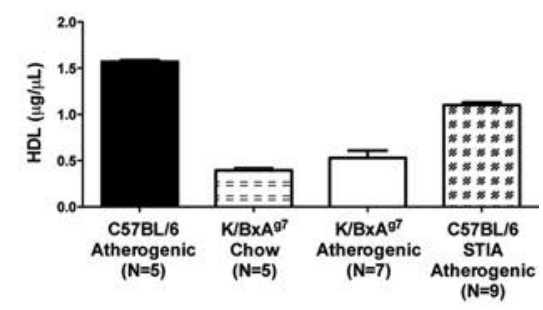

F.
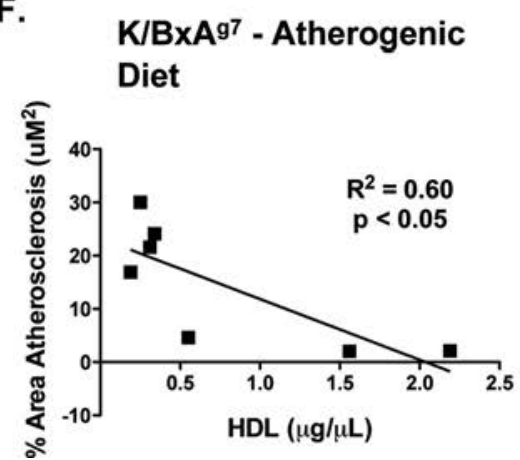

Figure $4 \quad \mathrm{~K} / \mathrm{BxA}^{97}$ mice develop dyslipidaemia. Serum was harvested from 27-week-old C57BL/6 (filled bars), 27-week-old C57BL/6 serum transfer-induced arthritis (STIA) (chequered bars), and 21-week-old K/BxA ${ }^{97}$ (open bars) mice fed an atherogenic diet for 9 weeks, or 23-week-old $\mathrm{K} / \mathrm{Bx}^{977}$ mice maintained on chow (horizontal bars). Mean \pm SEM (A) total cholesterol (TC), (B) low-density lipoprotein (LDL)/vLDL and (C) high-density lipoprotein $(\mathrm{HDL})$ are depicted. All t test comparisons between groups were statistically significant $(p<0.05)$ with the following exceptions: $\mathrm{TC}-\mathrm{K} / \mathrm{Bx} \mathrm{A}^{97}$ atherogenic versus chow, $\mathrm{LDL} / \mathrm{vLDL}-\mathrm{K} / \mathrm{Bx} \mathrm{A}^{97}$ and $\mathrm{C} 57 \mathrm{BL} / 6$ atherogenic versus $\mathrm{C} 57 \mathrm{BL} / 6 \mathrm{STIA}$ atherogenic, and $\mathrm{HDL}-\mathrm{K} / \mathrm{Bx} \mathrm{A}^{97}$ atherogenic versus chow. Linear regression analysis of (D) TC, (E) LDL/vLDL and (F) HDL versus atherosclerosis.

A.

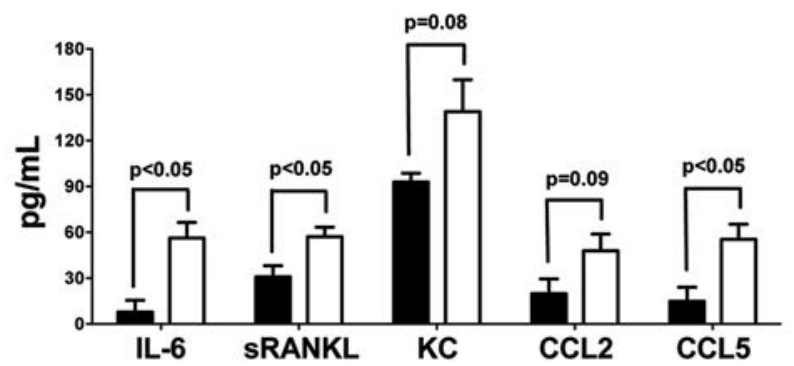

B. C57BL/6 Atherogenic $(\mathrm{N}=5)$
$\mathrm{K} / \mathrm{B} \times \mathrm{A}^{77}$ Atherogenic $(\mathrm{N}=7)$

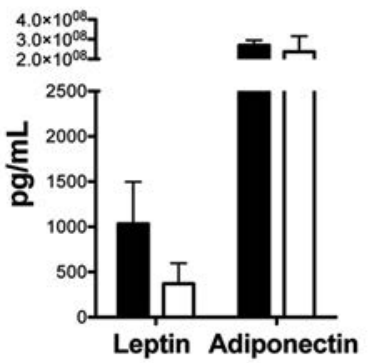

c.
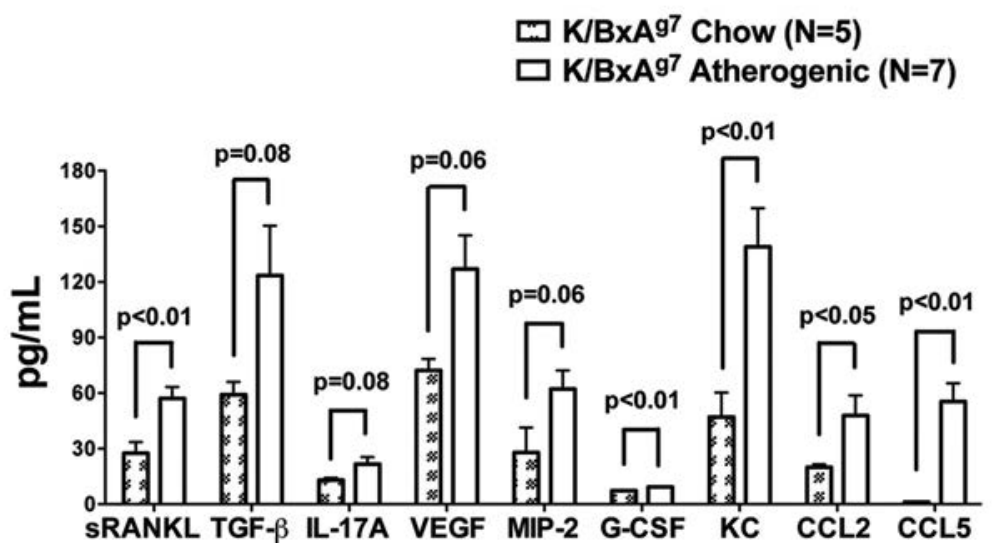

Figure 5 Altered serum cytokine/chemokine profiles in $\mathrm{K} / \mathrm{BxA}^{97}$ mice. (A) Serum cytokines and chemokines and (B) adipokines (mean \pm SEM) in C57BL/6 (filled bars) and $\mathrm{K} / \mathrm{BxA}^{97}$ (open bars) mice fed an atherogenic diet were measured via Luminex. (C) Serum cytokines and chemokines were measured via Luminex in 23-week-old $\mathrm{K} / \mathrm{BxA}^{\mathrm{g} 7}$ mice fed chow (chequered bars), or 21-week-old $\mathrm{K} / \mathrm{BxA}^{97}$ mice fed an atherogenic diet for 9 weeks (open bars). 
sRANKL and CCL5 were significantly greater $(\mathrm{p}<0.05)$, while $\mathrm{KC}$ and $\mathrm{CCL}-2$ trended toward significance in $\mathrm{K} / \mathrm{BxA} \mathrm{A}^{7}$ mice compared with C57BL/6 controls fed an atherogenic diet (figure 5A). Elevations in IL-21, IL-12/23 p40, tumour necrosis factor (TNF $\alpha$ ), MIP-2, CXCL10 and GM-CSF were also

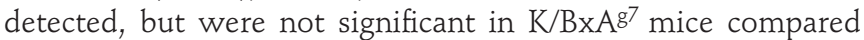
with controls (online figure 1 ). In contrast, VEGF, TGF- $\beta$, IL-4, IL-13, IL-1 $\alpha$, IL-1 $\beta$, IL-17A, G-CSF, CCL3, leptin and adiponectin were expressed at similar levels (figure $5 \mathrm{~B}$ and online figure 1) and IL-10, interferon $\gamma$, IL-2, IL-12 p70 and IL-23 p19 were undetectable (unpublished data). Further, sRANKL, G-CSF, KC, CCL2 and CCL5 were increased in $\mathrm{K} / \mathrm{BxA}^{87}$ mice fed an atherogenic diet compared with chow (figure 5C), while levels of the remaining cytokines and chemokines were unaffected by diet (online figure 1). Together, these data suggest that higher levels of circulating cytokines and chemokines, but not adipokines, may contribute to increased atherosclerosis in $\mathrm{K} / \mathrm{BxA}^{\mathrm{g} 7}$ mice.

TNF blockade improves arthritis and atherosclerosis in $\mathrm{K} / \mathrm{BxA}^{\mathrm{g} 7}$ mice

Etanercept is a TNF antagonist commonly employed to treat RA. ${ }^{17} \mathrm{~K} / \mathrm{BxA}^{87}$ mice on an atherogenic diet were treated biweekly with PBS or etanercept for 13 weeks. Administration of etanercept reduced arthritis severity (figure 6B), as indicated by a $0.2-0.4 \mathrm{~mm}$ decrease in ankle width, and by a 2.0 -fold reduction in joint clinical score, as compared with PBS-treated

A.

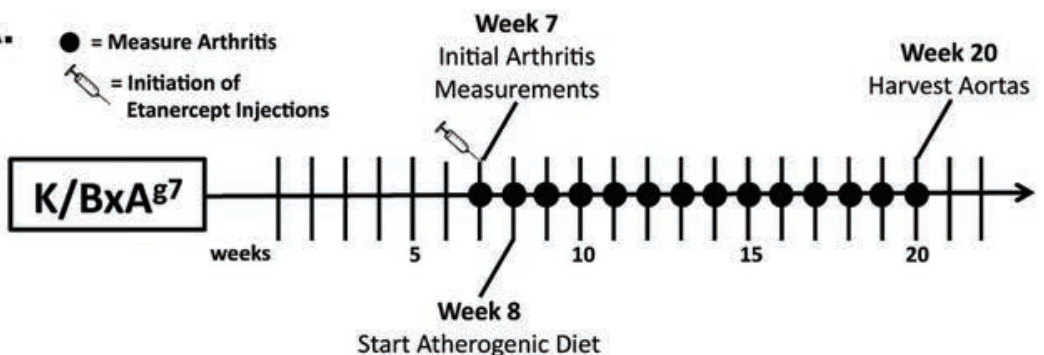

Start Atherogenic Diet
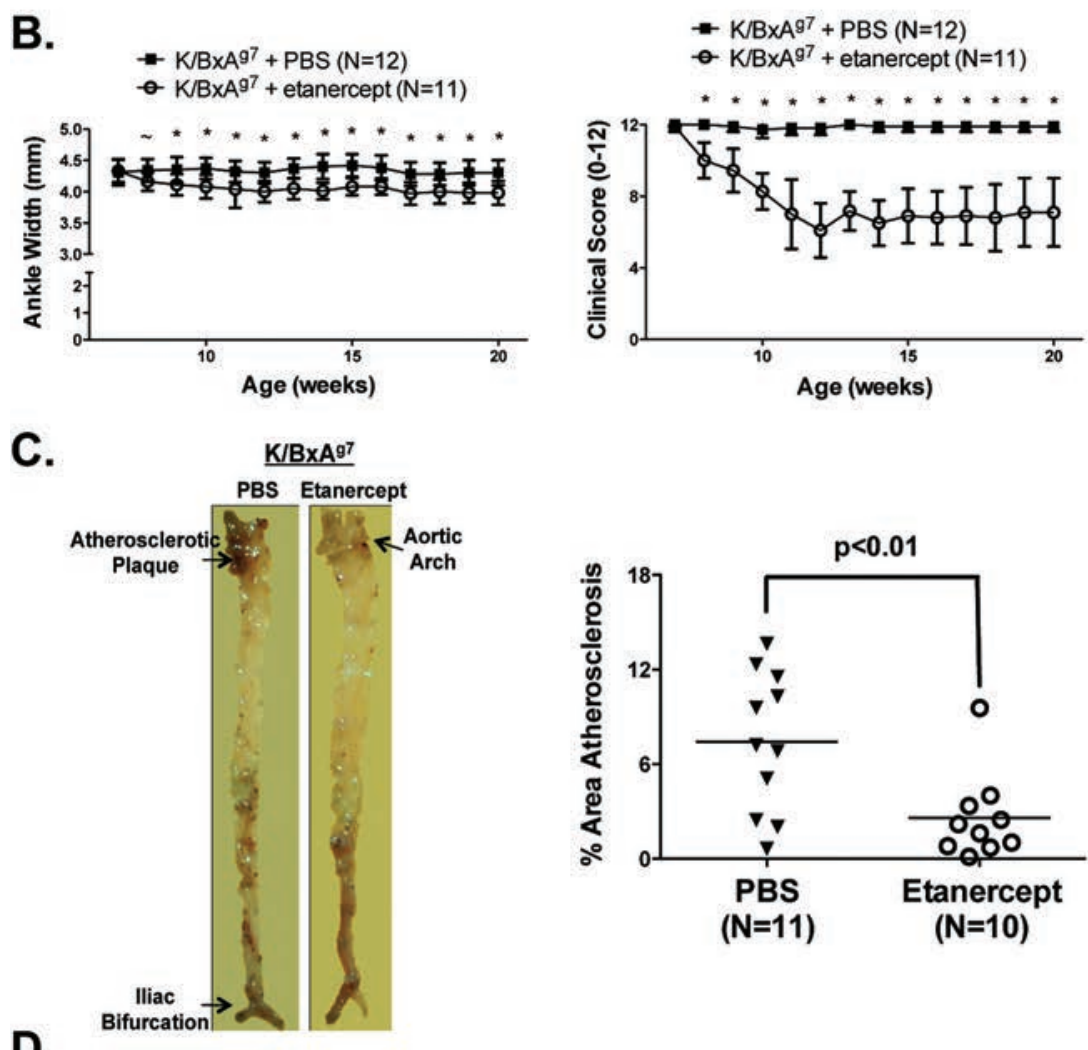

D.
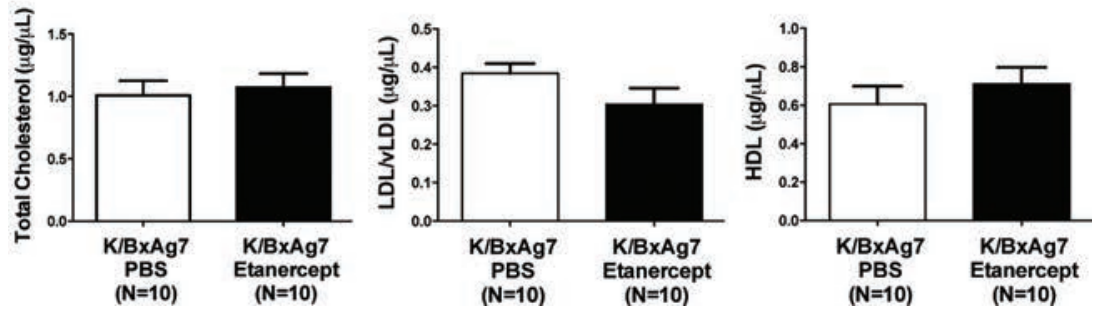

Figure 6 Improved arthritis, atherosclerosis and dyslipidaemia in $\mathrm{K} / \mathrm{BxA}^{\mathrm{g} 7}$ mice treated with etanercept. (A) Experimental timeline. (B) Arthritis severity, (C) mean \pm SEM\% area aortic atherosclerosis and (D) TC, LDL/vLDL and HDL levels in $\mathrm{K} / \mathrm{BxA}^{\mathrm{g} 7}$ animals treated with phosphate buffered saline (open) or etanercept (filled). $\sim$ denotes statistical significance at $p<0.05,{ }^{*}$ at $p<0.01$. 
controls. Atherosclerotic burden was reduced by 3.0-fold in etanercept-treated mice compared with controls (figure 6C). Further, etanercept therapy in $\mathrm{K} / \mathrm{BxA}^{87}$ mice reversed aortic valvulitis thickening (figure 3$),{ }^{10}$ and impaired valvular function (online Videos 1-4). TC, LDL/vLDL and HDL levels were unaffected by etanercept treatment (figure 6D). Together, these data demonstrate a link between arthritis severity and the development of atherosclerosis in $\mathrm{K} / \mathrm{BxA} \mathrm{A}^{87}$ mice.

\section{DISCUSSION}

Here, we characterised $\mathrm{K} / \mathrm{BxA}^{\mathrm{g} 7}$ mice as a unique model of arthritis/atherosclerosis that recapitulates the same sequence of events occurring in RA. Even passive transfer of arthritis triggers the development of atherosclerosis, suggesting that both disease states occur independently of the unique TCR (KRN) and MHC class II allele $\left(\mathrm{A}^{\mathrm{g} 7}\right)$ present in $\mathrm{K} / \mathrm{Bx} \mathrm{A}^{\mathrm{g} 7}$ mice. While previous studies have shown that mice lacking Fas ${ }^{18}$ or FasL, ${ }^{19}$ or that are on a genetically predisposed background (BWF1), ${ }^{20}$ develop SLE-like disease and enhanced atherosclerosis when fed a high fat diet, we are the first to generate a murine model of RA-like disease that is also susceptible to atherosclerosis. $\mathrm{K} / \mathrm{BxA}^{\mathrm{g} 7}$ mice also develop dyslipidaemia, and display increased serum levels of pro-inflammatory cytokines and chemokines. TNF blockade diminishes arthritis and atherosclerosis in $\mathrm{K} / \mathrm{BxA}^{\mathrm{g} 7}$ mice. Collectively, these data link arthritis and atherosclerosis as interdependent disease processes, and establish the $\mathrm{K} / \mathrm{BxA}^{\mathrm{g} 7}$ mouse as a unique model for preclinical testing of therapeutics for these disorders.

$\mathrm{K} / \mathrm{BxA}^{\mathrm{g} 7}$ mice develop a destructive inflammatory arthritis mirroring RA patients with severe or untreated disease. Unlike RA, there was no evidence of calcified aortic lesions or thrombotic events despite extensive atherosclerosis in $\mathrm{K} / \mathrm{BxA}^{\mathrm{g} 7}$ animals (unpublished data). Yet, $\mathrm{K} / \mathrm{BxA}^{\mathrm{g} 7}$ mice demonstrated a lipid paradox (diminished TC and HDL) that resembles the dyslipidaemia seen in RA patients with the greatest inflammatory burden. ${ }^{21}$ There was a significant inverse association between $\mathrm{HDL}$ levels and plaque area in $\mathrm{K} / \mathrm{BxA}^{\mathrm{g} 7}$ mice, consistent with previous studies showing an atheroprotective role of HDL in RA. ${ }^{4}$ However, treatment with etanercept improves arthritis and atherosclerosis without affecting lipid levels in $\mathrm{K} / \mathrm{BxA}^{\mathrm{g} 7}$ mice, suggesting a non-causative relationship between dyslipidaemia and atherosclerosis in these animals. Future studies will determine whether altering dyslipidaemia impacts the development of atherosclerosis in $\mathrm{K} / \mathrm{BxA}^{\mathrm{g} 7}$ mice.

Since cytokines and chemokines are potent orchestrators of inflammation, altered levels of these factors may contribute to the development of arthritis and vascular disease in $\mathrm{K} / \mathrm{BxA} \mathrm{A}^{\mathrm{g}}$ mice. Indeed, elevated levels of several inflammatory mediators were evident in $\mathrm{K} / \mathrm{BxA}^{\mathrm{g} 7}$ mice and TNF blockade led to improved arthritis and atherosclerosis. However, epidemiologic studies have yielded conflicting data on the effects of diseasemodifying treatments on RA disease activity and CV disease. Thus, dissecting the disease-specific effects of individual mediators will be critical to understanding the relationships among inflammatory arthritis, dyslipidaemia and atherosclerosis in $\mathrm{K} /$ $\mathrm{BxA}^{\mathrm{g} 7}$ mice as a model for RA-like disease.

Acknowledgements This work was supported by grants Driskill Fellow Scholarship award, NIH grant (AR07611) and NIH LRP to Shawn Rose, HHMI (57006753) to C Shad Thaxton, NIH grants (HL051387 and HL108795) to Douglas Vaughan, NIH grants (EB005866 and CA151880) to Thomas Meade, and NIH grants (AR050250, AR054796, Al092490 and HL108795) and Funds provided by Northwestern University, Feinberg School of Medicine to Harris Perlman. The authors thank Jungwha Lee for advice on statistical analyses.
Contributors All authors contributed to the manuscript.

Funding $\mathrm{NIH}$.

Competing interests None.

Provenance and peer review Not commissioned; externally peer reviewed.

Data sharing statement We will share all data and resources that relate to this manuscript.

Open Access This is an Open Access article distributed in accordance with the Creative Commons Attribution Non Commercial (CC BY-NC 3.0) license, which permits others to distribute, remix, adapt, build upon this work non-commercially, and license their derivative works on different terms, provided the original work is properly cited and the use is non-commercial. See: http://creativecommons.org/ licenses/by-nc/3.0/

\section{REFERENCES}

1. Pope RM, Perlman H. Rheumatoid Arthritis. In: Tsokos GC, eds. Current Molecular Medicine: Principles of Molecular Rheumatology. Totowa: Humana Press 2000:325-61

2. Aviña-Zubieta JA, Choi HK, Sadatsafavi M, et al. Risk of cardiovascular mortality in patients with rheumatoid arthritis: a meta-analysis of observational studies. Arthritis Rheum 2008;59:1690-7.

3. del Rincón ID, Williams K, Stern MP, et al. High incidence of cardiovascular events in a rheumatoid arthritis cohort not explained by traditional cardiac risk factors. Arthritis Rheum 2001;44:2737-45.

4. Toms TE, Symmons DP, Kitas GD. Dyslipidaemia in rheumatoid arthritis: the role of inflammation, drugs, lifestyle and genetic factors. Curr Vasc Pharmacol 2010;8:301-26.

5. Matsumoto I, Staub A, Benoist C, et al. Arthritis provoked by linked T and B cell recognition of a glycolytic enzyme. Science 1999;286:1732-5.

6. Ji H, Ohmura K, Mahmood U, et al. Arthritis critically dependent on innate immune system players. Immunity 2002;16:157-68.

7. Kyburz D, Corr M. The KRN mouse model of inflammatory arthritis. Springer Semin Immunopathol 2003;25:79-90.

8. Monach PA, Nigrovic PA, Chen M, et al. Neutrophils in a mouse model of autoantibody-mediated arthritis: critical producers of Fc receptor gamma, the receptor for $\mathrm{C} 5 \mathrm{a}$, and lymphocyte function-associated antigen 1. Arthritis Rheum 2010;62:753-64.

9. Korganow AS, Ji H, Mangialaio S, et al. From systemic T cell self-reactivity to organ-specific autoimmune disease via immunoglobulins. Immunity 1999;10:451-61.

10. Binstadt BA, Hebert JL, Ortiz-Lopez A, et al. The same systemic autoimmune disease provokes arthritis and endocarditis via distinct mechanisms. Proc Natl Acad Sci USA 2009;106:16758-63.

11. Basu D, Horvath S, Matsumoto I, et al. Molecular basis for recognition of an arthritic peptide and a foreign epitope on distinct MHC molecules by a single TCR. J Immunol 2000;164:5788-96.

12. Korganow AS, Duchatelle V, et al. Organ-specific disease provoked by systemic autoimmunity. Cell 1996;87:811-22.

13. Mandik-Nayak L, Wipke BT, Shih FF, et al. Despite ubiquitous autoantigen expression, arthritogenic autoantibody response initiates in the local lymph node. Proc Natl Acad Sci USA 2002;99:14368-73

14. Aubry MC, Maradit-Kremers $\mathrm{H}$, Reinalda MS, et al. Differences in atherosclerotic coronary heart disease between subjects with and without rheumatoid arthritis. J Rheumatol 2007;34:937-42

15. Ait-Oufella $\mathbf{H}$, Taleb S, Mallat Z, et al. Recent advances on the role of cytokines in atherosclerosis. Arterioscler Thromb Vasc Biol 2011;31:969-79.

16. Surmi BK, Hasty AH. The role of chemokines in recruitment of immune cells to the artery wall and adipose tissue. Vascul Pharmacol 2010;52:27-36.

17. Murray KM, Dahl SL. Recombinant human tumor necrosis factor receptor (p75) Fc fusion protein (TNFR:Fc) in rheumatoid arthritis. Ann Pharmacother 1997;31:1335-8.

18. Ma Z, Choudhury A, Kang SA, et al. Accelerated atherosclerosis in ApoE deficient lupus mouse models. Clin Immunol 2008;127:168-75.

19. Aprahamian T, Rifkin I, Bonegio R, et al. Impaired clearance of apoptotic cells promotes synergy between atherogenesis and autoimmune disease. J Exp Med 2004; 199:1121-31.

20. Hahn BH, Lourencço EV, McMahon M, et al. Pro-inflammatory high-density lipoproteins and atherosclerosis are induced in lupus-prone mice by a high-fat diet and leptin. Lupus 2010;19:913-17.

21. Choy E, Sattar N. Interpreting lipid levels in the context of high-grade inflammatory states with a focus on rheumatoid arthritis: a challenge to conventional cardiovascular risk actions. Ann Rheum Dis 2009;68:460-9. 